\title{
ANALISIS EKOLOGI BERWAWASAN GENDER (ECOFEMINISM) DALAM KARYA SASTRA PARA SASTRAWAN LAMONGAN
}

\author{
Kiki Astrea \\ Anisa Ulfah \\ Universitas Islam Darul `Ulum Lamongan \\ Email: kikiastrea@unisda.ac.id
}

\begin{abstract}
The purpose of this study is the discovery of (1) the influence of political ecological values (2) the influence of cultural ecological values (3) the influence of social ecological values, and (4) the influence of the ecological values of imperialism heritage. The data in this study are data about (1) the influence of political ecological values (2) The influence of cultural ecological values (3) The influence of social ecological values, and (4) the influence of the ecological values of imperialism heritage. Data sources are obtained from documentation and interviews. The data collection techniques are carried out with documentation and interviews. Data analysis techniques use interactive techniques. Data validation uses triangulation, both triangulation of theories, data, and methods. The research findings can be described include: (1) the influence of political ecological values (2) The influence of cultural ecological values (3) The influence of social ecological values, and (4) the influence of the ecological values of imperialism inheritance in the literary text writer in Lamongan.
\end{abstract}

Keywords: Ecology, Gender (Ecofeminism), Literature and Literature Works

\begin{abstract}
Abstrak : Tujuan dari penelitian ini adalah penemuan (1) pengaruh nilai-nilai ekologi politik (2) Pengaruh nilai-nilai ekologi Budaya (3) Pengaruh nilai-nilai ekologi social, dan (4) pengaruh nilai-nilai ekologi warisan imperialism. Data dalam penelitian ini berupa data tentang (1) pengaruh nilai-nilai ekologi politik (2) Pengaruh nilai-nilai ekologi Budaya (3) Pengaruh nilai-nilai ekologi social, dan (4) pengaruh nilai-nilai ekologi warisan imperialism. Sumber data diperoleh dari dokumentasi dan wawancara. Adapun teknik pengumpulan data dilakukan dengan dokumentasi dan wawancara. Teknik analisis data menggunakan teknik interaktif. Validasi data menggunakan triangulasi, baik triangulasi teori, data, dan metode. Hasil temuan penelitian dapat dideskripsikan meliputi: (1) pengaruh nilai-nilai ekologi politik (2) Pengaruh nilai-nilai ekologi Budaya (3) Pengaruh nilai-nilai ekologi social, dan (4) pengaruh nilai-nilai ekologi warisan imperialism dalam teks sastra para sastrawan di Lamongan.
\end{abstract}

Kata kunci : Ekologi , Gender (Ecofeminism), Karya Sastra, dan Sastrawan

\section{PENDAHULUAN}

Karya sastra adalah suatu bentuk tulisan yang indah dan bermanfaat bagi pembaca dan merupakan hasil kreativitas pengarang dalam mencermati realitas (Sutardi, 2011 :1-2). Karya sastra tidak dapat lepas dari unsur pengarang, masyarakat, dan pembaca. Karya sastra dapat merupakan potret kehidupan masyarakat (Sariban, 2009: 7). Berkaitan dengan upaya memahami dan mengungkap hubungan pengarang dengan fakta dan realitas sosial, imajinasi kreativitas pengarang, serta nilai-nilai yang terkandung dalam sebuah teks karya sastra, dalam penelitian ini dipilih karya 
Humanis Vol 11 No 2

besar dari sastrawan Lamongan sebagai objek penelitian dengan menggunakan pendekatan ekologi sastra berwawasan feminism (ecofeminism). Pendekatan ini diharapkan dapat mengungkap pengaruh pengaruh ekologi yang mempengaruhi para sastrawan Lamongan yang terdapat dalam teks sastra. Penelitian ini juga diharapkan dapat mengungkap kebesaran pengarang yang memiliki karakter dalam kepengarangannya dan dapat dipertanggungjawabkan secara ilmiah. Oleh karena itu, tugas dalam penelitian sastra tidak sekadar harus menafsirkan apa saja yang dipandang aneh dalam karya, melainkan harus memberikan penilaiaan pertanggungjawaban. Penelitian sebaiknya mampu memberikan evaluasi terhadap karya sastra sampai proses penciptaannya. Dari sini akan muncul pula karya sastra yang bermutu dan manakah karya sastra yang "kacangan" (Endraswara, 2006:11).

Berkaitan dengan kualitas sebuah karya sastra Luckas menegaskan persoalan yang mendasar dari karya sastra modernis adalah hilangnya totalitas. Totalitas yang hilang membuat karya sastra modernis gagal dalam menciptakan tipe atau karakter. Sastrawan besar adalah seorang pengarang yang hasil karyanya berhasil melahirkan "karakter kemanusian" yang abadi. Tipe atau karakter yang dimaksud adalah suatu bentuk figuratif yang menunjukkan kualitas esensi pemikiran yang terdalam suatu zaman. Sastrawan yang hebat adalah pengarang yang mampu menghasilkan karya keturunan Homer, yaitu sastrawan yang mampu menggambarkan dunia alamiah mereka dan membagikan kekuatan pengalaman hidup, serta evolusi masyarakat tempat pengarang itu hidup (Anwar, 2010: 54).

Oleh karena itu, dalam penelitian ini tidak sekadar harus menafsirkan apa saja yang dipandang aneh dalam karya, melainkan harus memberikan penilaiaan pertanggungjawaban. Penelitian ini harus mampu memberikan gambaran pengaruh- pengaruh ecofeminism yang diungkap dari karya sastra para sastrawan Lamongan.

\section{METODE PENELITIAN}

Jenis penelitian yang digunakan dalam kajian ini adalah kualitatif deskriptif. Metode kualitatif memberikan perhatian terhadap data alamiah, data dalam hubungannnya dengan konteks keberadaannya. Caracara itulah yang mendorong metode kualitatif dianggap sebagai multimetode sebab penelitian pada gilirannya melibatkan sejumlah besar gejala social yang relevan. Penelitian ini juga menggunakan metode analisis isi(Content analysis). Pendekatan penelitian yang digunakan adalah kritik sastra feminis.

\section{TEORI DAN PEMBAHASAN}

Karya sastra sebagai sebuah kreativitas memiliki pola-pola yang dianggap oleh masyarakat sebagai sistem. Pada kaitan ini, Teeuw (1983:2) mengungkapkan bahwa sastra berada di antara 'inovasi dan konvensi'. Inovasi dari karya sastra terletak pada hasil kreativitas pengarang dalam memahami realitas sebagai fenomena. Adapun konvensi terletak pada hakikat 
yang melekat pada karya sastra dengan adanya sistem yang melingkarinya.

Seorang menulis karya sastra akan terikat pada karya-karya terduhulunya yang telah diyakini oleh masyarakat sebagai sastra sembari memunculkan beberapa inovasiinovasi, baik pada isi maupun bentuk. Adanya pola-pola di dalam karya sastra yang menjadikan munculnya studi sastra untuk memahami secara menyeluruh dengan adanya sifat- sifat yang melekat. Cara paling mudah untuk memahami yang tergolong sastra dan bukan sastra, yakni dengan membedakan pada sisi bahasa yang digunakan. Karya sastra selalu menggunakan bahasa sebagai medium untuk menyampaikan pesan kepada pembaca. Dalam praktiknya, ada perbedaan antara bahasa yang digunakan dalam kehidupan sehari-hari dengan bahasa yang digunakan di dalam karya sastra.

Istilah Ekologi merupakan bentukan dari kata oikos dan logos. Dalam bahasa Yunani oikos berarti rumah-tempat tinggal: tempat tinggal semua perempuan dan laki-laki, hewan, tumbuhan, air, tanah, udara, dan matahari. Ekologi lebih bisa dipahami sebagai ilmu yang mempelajari hubungan antarmanusia dan lingkungan hidup, mengaitkan ilmu kemanusiaan dan ilmu alam, bersifat multidisipliner (Yuwana,

1:2016). Ekologi sastra dapat diartikan sebagai kajian ilmiah tentang hubungan antara karya sastra dengan lingkungan (ecology) yang mempengaruhi karya sastra tersebut. Pengaruh sebuah lingkungan dimana pengarang itu
Humanis Vol 11 No 2

berada adalah suata permasalahan yang wajar.

Oleh karena, pengarang akan selalu dipengaruhi oleh subyek kolektif di mana pengarang itu hidup dalam suatu lingkungan. Baik lingkungan budaya, politik, system social, ekonomi dan lain sebagainnya. Adapun Konstruksi pemikiran ekologi feminism berangkat dari terminology ecofeminism dimunculkan oleh francoise d'Eaubonne dalam sebuah bukunya yang berjudul (feminism dan kematian). Buku yang mengupas tentang perempuan dan persoalan ekologi dikaiatkan secara multidimensional (Yuwana, 2016:168). memperkuat. Keduanya hendak membangun pandangan terhadap dunia dan praktiknya yang tidak berdasarkan dominasi tertentu.

Kritik sastra feminis adalah sebuah kritik yang memandang sastra dengan kesadaran khusus akan adanya jenis kelamin yang banyak berhubungan dengan budaya sastra dan kehidupan manusia. Kritik sastra feminis merupakan salah satu ragam kritik sastra yang memanfaatkan teori feminisme dalam menginterpretasi dan memberikan evaluasi terhadap karya sastra (Wiyatmi,

2012 :

$1)$.

Berkaitan dengan temuan dan pembahasan dalam penelitian ini yang berobyek pada sastrawan dalam menghasilkan karya sastranya ditinjau dari pendekatan ecofeminisme dalam karya sastra. Hal tersebut berangkat dari Konstruksi pemikiran ekologi feminism berangkat dari 
terminology ecofeminism dimunculkan oleh francoise d'Eaubonne dalam sebuah bukunya yang berjudul (feminism dan kematian). Buku yang mengupas tentang perempuan dan persoalan ekologi dikaiatkan secara multidimensional (Yuwana, 2016:168). Gerakan feminism dan ekologi mempunyai tujuan yang saling memperkuat. Keduanya hendak membangun pandangan terhadap dunia dan praktiknya yang tidak berdasarkan dominasi tertentu. Oleh karena, temuan penelitian terhadap karya sastra pengarang Lamongan dapat diklasifikasikan sebagai berikut.

\section{Pengaruh Nilai-Nilai Ekologi Politik dalam Teks Sastra}

$\begin{aligned} & \text { Pengaruh nilai Politik } \\ & \text { dalam }\end{aligned}$

ekologi sastra feminim di Lamongan, kita Jumpai dalam Novel Karya Rodli TL, karya tersebut berseting pada tahun 1998 pada masa pergolokan politik di tanah air, pada masa pergantian rezim orde baru ke orde reformasi. Novel ini cukup representatip dalam menggambarkan seorang tokoh perempuan yang sedang menggambarkan nilai-nilai hidup perempuan yang pemberani dan memiliki sikap integritas yang tinggi. Sikap dalam memahami dunia pergerakan di kampus antara idealisme dan realitas yang dialami sesungguhnya dalam sosial , politik dan kemasyarakatan.

Pengaruh Nilai-Nilai Ekologi Budaya dalam Teks Sastra
Humanis Vol 11 No 2

Teks sastra yang

menunjukkan

keterpengaruhan akan nilai-nilai ekologi Budaya, tampak pada karya A. Zaini dalam kumpulan Novel Mahar Cinta Berair . Menceritakan bagaimana seorang gadis merasa tidak mendapatkan keadilan cinta dengan laki-laki pujaan. Ia harus terpaksa memendam rasa cinta atas ketidakadilan persepsi perempuan di masyarakat. Begitu juga dalam kumpulan puisi sungai asal karya Pringgo HR. Yang berjudul Wanita, dalam puisi ini mendiskripsikan bagaimana sebenarnya perempuan perkasa itu, pengaruh nilai budaya Jawa, Ajaran Agama, dan roman klasik sebagi daya ungkap oleh penulis.

\section{Pengaruh Nilai-Nilai Ekologi Sosial dalam Teks Sastra}

Teks sastra yang

menunjukkan

keterpengaruhan akan nilai-nilai ekologi sosial tampak pada karya Rodli Murtadlo, dalam kumpulan cerpen Kembang Sepatu. Pada cerpen yang berjudul perempuankah Aku, Menceritakan bagaimana seorang perempuan yang menyangsikan keperempuannya. Nilai- nilai sosial dan etika dimasyarakat membuat sang tokoh mencari jati diri yang sebenarnya. Kodrat keperempuannya dan naluri kelakiannya pertanyaan besar akan takdir hidupnya, dan anggapan-anggapan masyarakat terhdap dirinya. 


\section{Pengaruh Nilai-Nilai Ekologi}

Warisan Imperialism dalam Teks

\section{Sastra}

Teks sastra yang

menunjukkan

pengaruh nilai-nilai ekologi warisan

imperialisme dapat ditemukan dalam antologi Cerpen, Parade Tapeng karya Cak Sariban. Dua judul yang menonjol keterpengaruhan akan warisan kolonial adalah pada cerpen dengan judul Tubuh Nihil dan Abortus. Tubuh Nihil menceritakan seoarang tokoh Bandit (sebagai tokoh abdsurd) pemimpin yang kuat dan kolot. Semua kebijakannya harus terlaksana, warisan budaya memimpin kolonial masih lekat pada gaya kepemimpinannya.

\section{SIMPUL}

AN

Berdasarkan temuan dari penelitian

ini dapat disimpulkan bahwa hasil penelitian terhadap karya sastra yang ditulis oleh sastrawan Lamongan yang bermuatan ecofeminism dapat diklasifikasika ke dalam empat jenis, Pengaruh nilai-nilai ekologi politik dalam teks Sastra, Pengaruh nilai-nilai ekologi Budaya dalam Teks sastra, . Pengaruh nilai-nilai ekologi social dalam teks sastra, dan pengaruh nilai-nilai ekologi warisan imperialism dalam teks sastra.

Temuan tersebut muncul dikarenakan tema-tema karya sastra yang ditulis sastrawan Lamongan syarat memberikan pengaruh penulis terhadap penggolongan ecofemenism.

\section{DAFTAR PUSTAKA}

\author{
Abrams, M.H. 1981. The Mirror and \\ The Lamp. Oxford: Oxford \\ University Press.
}
Endraswara, $\quad$ Suwardi. 2013. Metodologi Penelitian Sastra: Epistemologi, Model, Teori, dan Aplikasi. Yogyakarta: CAPS

Fakih, Mansour. 2013. Analisis Gender dan Transformasi

Sosial. Yogyakarta: Pustaka Pelajar.

Harmaji.2007: Sungai Asal (antologi sajak). Pustaka Pujangga; Lamongan

Murtadho, Rodhi.2004. Kembang Sepatu. (antologi cerpen). Pustaka Ilalang. Lamongan

Nurgiyantoro, Burhan. 2015. Teori Pengkajian Fiksi. Yogyakarta: Gadjah Mada University Press.

Ratna, Nyoman Kutha. 2010. Sastra dan Cultural Studies: Representasi Fiksi dan Fakta. Yogyakarta: Pustaka Pelajar.

Metode, dan Teknik

Penelitian Sastra. Yogyakarta: Pustaka Pelajar.

Rodli, TL. 2006. Dazedlove (novel).

Pustaka Ilalang, Lamongan

Sariban. 2009. Teori dan Penerapan Penelitian Sastra. Surabaya: Lentera Cendikia. 
Sariban, 2001. Parade Topeng

(Antologi

Cerpen). FKIP Unisda Lamongan

Sugihastuti dan Suharto. 2015. Kritik

Sastra Feminis: Teori dan

Aplikasinya. Yogyakarta:

Pustaka Pelajar.

Sutardi. 2011. Apresiasi Sastra: Teori, Aplikasi, dan Pembelajarannya. Lamongan: Pustaka Ilalang.

Wiyatmi. 2012. Kritik Sastra Feminis:

Teori dan Aplikasinya dalam

Sastra Indonesia. Yogyakarta:

Ombak

Wardani, Nugraheni Eko. 2009.

Makna Totalitas dalam Karya

Sastra. Surakarta: UNS Press.

Yuwana Sudikan, Setya. 2001. Metode

Penelitian Sastra Lisan.

Surabaya: Citra Wacana

Yuwana Sudikan, Setya. 2016.

Ekologi

Sastra. Surabaya:Pustaka Ilalang.

Zaini. A. 2015. Mahar Cinta Berair Mata (novel). Pustaka Ilalang, Lamongan 